\title{
Pengaruh Dolar Singapura dan Fluktuasi Inflasi Terhadap Pergerakan Harga IHSG
}

\author{
Arif Surahman ${ }^{1)}$; Rudy Bodewyn Mangasa Tua ${ }^{2)}$
}

1,2) Universitas Pamulang, email: dosen001176@unpam.ac.id; dosen01033@unpam.ac.id

ARTICLES
INFORMATION ABSTRACT

\section{JURNAL SEKURITAS}

(Saham, Ekonomi, Keuangan dan Investasi )

Vol.4, No.1, September 2020 Halaman : $24-33$

(C) LPPM \& Prodi Manajemen UNVERSITAS PAMULANG

\section{ISSN (online) : 2581-2777 ISSN (print) : : 2581-2696}

\section{Keyword :}

IHSG; Inflasi; Dolar; Singapura; Pengaruh

JEL. classification :

C33, G21, G24, N15, N25

\section{Contact Author :}

PRODI MANAJEMEN UNPAM

JL.Surya Kencana No.1

Pamulang Tangerang Selatan Banten

Telp. (021) 7412566, Fax (021) 7412491 Email :

sekuritas@unpam.ac.id
Penelitian dibuat untuk menyelidiki bagaimana fluktuasi harga Dolar Singapura dan fluktuasi Inflasi Indonesia dapat berpengaruh terhadap pergerakan harga IHSG. Kami menggunakan data bulanan, selama 31 bulan yang diambil menggunakan data sekunder dari internet. Kami menggunakan uji regresi dan mendapatkan hasil yang berbeda dengan penelitian-penelitian yang dilakukan oleh Jayanti dkk. (2014) serta Sathyanarayana dan Garbesa (2018), yang menemukan bahwa fluktuasi nilai Inflasi Indonesia tidak berpengaruh signifikan terhadap IHSG. Berlawanan dengan temuan-temuan mereka, penelitian kami telah menemukan adanya hubungan yang negatif signifikan terhadap fluktuasi Inflasi terhadap Indeks Indonesia (IHSG). Selain itu, kami juga menemukan bahwa Dolar Singapura berpengaruh signifikan negatif terhadap IHSG.

This research is made to examine how does the price fluctuation of Singapore Dollar and the fluctuation of Indonesians Inflation rate can influenced the price of Indonesian Stock Exchange Index. We've used mothly data for 31 month that was taken by using secondary data from the internet. We've used Regression and have gained a different results that has varied from research that were conducted by Jayanti (2014) and Garbesa (2018), which concluded that the fluctuations of indonesian inflation rate does not significantly effect the IHSG. Contrary to that findings, our research has founded a negative significant relationship between inflation rates fluctuations towards Indonesian's Index (IHSG). Besides that, we have also founded that the Singapore Dollar had a negative significant influence towards IHSG. 


\section{A. PENDAHULUAN}

Aktivitas perdagangan saham di Pasar Modal Indonesia semakin meraih momentum baru di mata para investor-investor pemula. Modal utama yang diperlukan ketika beraktivitas di pasar modal adalah informasi, dan salah satu informasi yang paling penting untuk menilai transaksi pembelian atau penjualan yang menguntungkan adalah fluktuasi harga Indeks Saham Gabungan atau yang terkenal dengan sebutan IHSG (Purwanto \& Hendy, 2006: 47). Lebih lanjut, naik atau turunnya harga IHSG juga selalu dihubung-hubungkan dengan kondisi perekonomian Indonesia. hal ini sebagaimana dikatakan oleh kepala riset Bahana Sekuritas, Lucky Ariesandi didalam tulisan Akhmad Suryahadi (2019). Oleh sebab itu, pengkajian perlu dilakukan untuk mengetahui hal-hal apa sajakah yang berperan terhadap fluktuasi IHSG.

Beberapa penelitian telah berhasil menemukan beberapa hal mengenai apa-apa saja yang menyebabkan harga IHSG berfluktuasi. Salah satunya adalah hasil penelitian Jayanti dan kawan-kawan (2014) yang menemukan bahwa inflasi tidak mempengaruhi IHSG. Selain itu, Sathyanarayana dan Garbesa (2018) dengan menggunakan data-data dari pasar modal India, Austria, Belgium, Kanada, Chile, Indonesia dan beberapa negara lain juga menemukan bahwa inflasi tidak memiliki pengaruh terhadap harga IHSG. Lebih lanjut, penelitian yang dilakukan oleh Listriono dan Nuraina (2015) menemukan hal yang berlawanan, yaitu inflasi berpengaruh terhadap IHSG. Kesimpulan yang dapat ditarik dari uraian ini adalah, bahwa pengaruh inflasi terhadap pergerakan IHSG belum mendapatkan hasil akhir yang pasti mengenai apakah fluktuasi inflasi memiliki pengaruh yang signifikan atau tidak terhadap IHSG. Karena itu, penelitian yang dilakukan pada jurnal ini bermaksud untuk menyelidiki dan memberikan kontribusi terhadap bagaimana pengaruh fluktuasi nilai inflasi terhadap IHSG.

Perekonomian Indonesia yang terbuka terhadap investor-investor asing dan juga kreditor-kreditor asing mengakibatkan nilai tukar Rupiah mengalami fluktuasi terhadap mata uang negara lain. "Naik-turunnya nilai tukar Rupiah terhadap mata uang negara lain dapat meningkatkan biaya bahan baku, mesin dan peralatan yang di impor ke Indonesia juga mengalami kenaikan dan penurunan. Hal ini kemudian dapat menyebabkan fluktuasi biaya produksi" (Jayanti, Darminto, Sudjana, 2014). Efek dari hal ini lebih lanjut akan menyebabkan keuntungan perusahaan berkurang dan mengalami ketidak pastian yang tinggi. Akibatnya, investasi di pasar modal akan berkurang sehingga IHSG akan mengalami penurunan. Penelitian yang dilakukan oleh Nugroho (2008) berhasil menemukan bahwa melemahnya Rupiah terhadap US Dolar bisa menurunkan harga-harga saham pada perusahaan-perusahaan di Indonesia.

Penelitian tentang bagaimana fluktuasi nilai tukar US Dolar terhadap IHSG sudah banyak mendapat perhatian dari para peneliti di Indonesia. Akan tetapi, masih sedikit penelitian yang mengkaji bagaimana efek dari Dolar Singapura terhadap fluktuasi IHSG. Sebagai contoh Yurioputra (2015) menemukan bahwa return IHSG dengan return yang didapatkan dari perdagangan forex antara Rupiah dengan Dolar Singapura tidak memiliki hubungan jangka panjang yang berarti.

Keterkaitan antara fluktuasi Dolar Singapura terhadap IHSG merupakan suatu hal yang menarik untuk diselidiki karena negara Singapura adalah pemberi hutang terbesar kepada Indonesia disamping negara Amerika yang berada diposisi kedua. Bank Indonesia mencatat bahwa pada tahun 2017, negara Singapura sudah memberikan hutang kepada Indonesia sebanyak 707 Trilyun Rupiah (Putra, 2017). Tentunya hutang sebanyak itu akan memiliki dampak yang besar terhadap perekonomian Indonesia ketika sudah jatuh tempo. Oleh karena itu, imbas dari fluktuasi nilai kurs Dolar Singapura bisa berefek kepada kepercayaan investor untuk melakukan investasi sehingga hal ini diduga bisa berpengaruh terhadap fluktuasi IHSG. 
Perumusan masalah dari artikel jurnal ini adalah sebagai berikut :

1. Apakah terdapat keterkaitan antara inflasi terhadap IHSG?

2. Apakah terdapat keterkaitan antara nilai Dolar Singapura terhadap IHSG ?

3. Apakah terdapat keterkaitan secara simultan antara tingkat inflasi, nilai Dolar Singapura terhadap IHSG ?

\section{Kerangka Pemikiran \& Hipotesis}

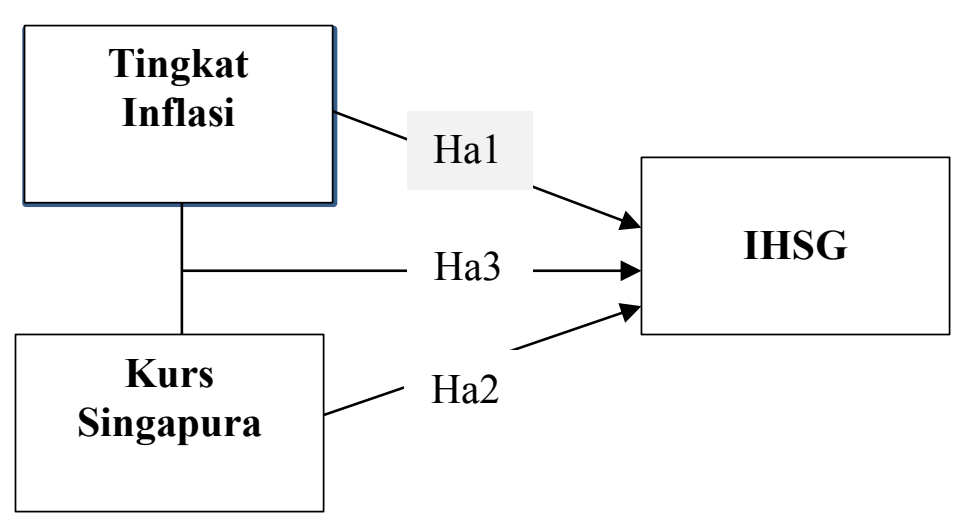

\section{Gambar 1: Bagan Kerangka Berfikir}

\section{Hipotesis Penelitian}

Ha1 : Inflasi berpengaruh terhadap IHSG

Ha 2 : Quotasi Kurs Dolar Singapura berpengaruh terhadap IHSG

Ha 3 : Tingkat Inflasi dan Dolar Singapura berpengaruh secara simultan Terhadap Harga IHSG.

\section{B. KAJIAN LITERATUR}

\section{Inflasi}

Inflasi adalah keadaan pada suatu perekonomian pada saat harga-harga mengalami kenaikan (Sukirno 2011). Definisi lainnya yang dikemukakan oleh Budiono (2013) membahas inflasi dari segi kecenderungan kenaikan harga secara konsisten dari waktu kewaktu. Cara mencari nilai inflasi menurut Sukirno (2011) adalah dengan memperhatikan Consumers Price Index. Nilai inflasi didapatkan dengan mengurangi Indeks Harga tahun sekarang dengan Indeks Harga tahun sebelumnya relatif terhadap indeks harga tahun sebelumnya kemudian dikalikan 100.

\section{Saham}

"Saham merupakan tanda kepemilikan terhadap aset-aset perusahaan dari perusahaan yang menerbitkan saham" (Dewi\&Rama, 2019). Tempat memperjual-belikan saham ada di IDX. Disana terdapat "6 macam Indeks saham yaitu IHSG, Indeks Sektoral, Indeks LQ45, Indeks Individual, Jakarta Islamic Index dan Indeks Kompas 100" (Sunardi, 2018).

\section{IHSG}

Indeks Harga Saham Gabungan merupakan sebuah kombinasi dari beberapa saham milik perusahaan terbaik atau yang dikenal dengan perusahaan "Bluechips" yang terdapat di Indonesia. IHSG merupakan "sebuah nilai yang digunakan untuk mengukur kinerja sebuah gabungan saham" (Sunariyah, 2011). "IHSG mulai diperkenalkan pertama kali yaitu pada tanggal 1 April 1983 pada tanggal 10 Agustus 1982 dengan jumlah saham yang tercatat pada waktu itu adalah sebanyak 13 saham" (Listriono \& Nuraina, 2015).

Jurnal SEKURITAS (Saham, Ekonomi, Keuangan dan Investasi ), Vol.4, No.1, September 2020... .26 


\section{Kurs}

Kurs adalah "banyaknya Rupiah yang diperlukan untuk mendapatkan satu unit mata uang negara lain" (Sukirno, 2011). Fluktuasi nilai tukar antara Indonesia dengan negara lain akan mempengaruhi perekonomian secara luas, terutama dalam hal ekspor dan impor. "Pada saat terjadi depresiasi mata uang pihak eksportir diuntungkan karena harga relatif produk ekspor Indonesia yang menjadi lebih murah. Sebaliknya, depresiasi rupiah merugikan importir dan debitur utang luar negeri dengan meningkatnya biaya impor dan beban pembayaran utang LN (ekivalen dalam mata uang domestik)" (Nugroho dkk., 2010).

\section{Penelitian Terdahulu}

Jayanti, Darminto \& Sudjana (2014) menemukan bahwa, "variabel tingkat inflasi tidak berpengaruh signifikan terhadap IHSG". Pada penelitian tersebut juga ditemukan bahwa tingkat suku bunga SBI dan kurs Dolar Amerika berpengaruh negatif dan signifikan terhadap IHSG. Sathyanarayana dan Gargesa (2018) dengan menggunakan data panel dari negara India, Austria, Belgium, Kanada, Chili, China, Perancis, Irlandia, Brazil, Indonesia, Jepang, Meksiko, Spanyol, Turki dan Australia yang diregresikan terhadap indeks harga saham dari masing-masing negara, tidak menemukan adanya pengaruh antara Inflasi dengan IHSG. Listriono dan Nuraina (2015) menemukan pengaruh yang signifikan antara Inflasi, BI Rate dan Kurs Dollar (USD/IDR) terhadap IHSG. Penelitian yang dilakukan oleh Yurioputra (2015) menemukan bahwa nilai kointegrasi tidak menunjukkan adanya hubungan pengaruh jangka panjang antara kurs Dolar Singapura terhadap IHSG.

\section{METODE PENELITIAN}

Metode kuantitatif asosiatif digunakan pada penelitian ini, caranya adalah dengan "mengolah data yang bersifat numerik dengan tujuan untuk mengetahui pengaruh ataupun juga hubungan antara dua variabel atau lebih"(Sugiyono, 2003). Selanjutnya, sampel data ditentukan dengan metode purposive sampling dengan bentuk data yang diambil menggunakan kriteria tertentu. Data yang digunakan berasal dari data sekunder, yaitu berupa informasi yang didapat dari Website Yahoo Finance dan website Bank Indonesia dan Website Departemen Perdagangan. Adapun data yang digunakan adalah data Inflasi, data harga IHSG dan data kurs Dolar Singapura.

Kemudian pengolahan data dilakukan dengan membuat regresi multivariat dengan memanfaatkan SPSS 20. Variabel independen dari model adalah Inflasi dan kurs Dolar Singapura, sedangkan variabel dependennya adalah harga IHSG. Sebelum regresi dibuat, maka dilakukan pengujian koefisien korelasi dan interpretasi koefisien Determinasi. Untuk mendapatkan hasil regresi yang terbaik tanpa ada masalah, maka pengolahan data dilakukan dengan melakukan pengujian asumsi klasik, Uji-F serta Uji-t. 


\section{HASIL DAN PEMBAHASAN}

Dari hasil SPSS 20 ditemukan bahwa model mengalami permasalahan heteroskedastisitas dan otokorelasi. Pengolahan data kemudian dilanjutkan dengan melakukan transformasi Cochrane Orcutt. Transformasi ini tidak mengubah esensi dari data-data yang akan diuji. Setelah dilakukan transformasi dengan metode tersebut, maka peneliti berhasil menemukan bahwa fluktuasi inflasi dan Dolar Singapura secara signifikan berpengaruh terhadap Indeks Harga Saham Indonesia. Selain itu, masalah heteroskedastisitas dan otokorelasi sudah dapat teratasi.

\section{Analisa Deskriptif}

Tabel 1. Statistika Deskriptif

\begin{tabular}{|l|r|r|r|}
\hline & \multicolumn{1}{|c|}{ Mean } & \multicolumn{1}{c|}{$\begin{array}{c}\text { Std. } \\
\text { Deviation }\end{array}$} & \multicolumn{1}{c|}{ N } \\
\hline LAG_IHSG & 2210,2499 & 233,23321 & 29 \\
LAG_INFLASI & 1,1250 &, 20310 & 29 \\
LAG_SGD & 3715,0221 & 280,47711 & 29 \\
\hline
\end{tabular}

Sumber: SPSS 20

Dengan menggunakan sampel 29 data. Diketahui bahwa, nilai rata-rata (mean) data yaitu IHSG sebesar 2210,2499, INFLASI sebesar 1,1250 dan SGD sebesar 3715,0221. Selanjutnya, nilai standar deviasi variabel IHSG sebesar 233,23321, INFLASI sebesar 0,20310 , dan SGD sebesar 280,47711.

\section{Uji Koefisien Korelasi}

Tabel 2: Nilai Pengujian Korelasi

\begin{tabular}{|ll|r|r|r|}
\hline & & LAG_IHSG & LAG_INFLASI & LAG_SGD \\
\hline Pearson & LAG_IHSG & 1,000 &,- 350 &,- 588 \\
& LAG_INFLASI &,- 350 & 1,000 &, 058 \\
& LAG_SGD &,- 588 &, 058 & 1,000 \\
\hline Sig. (1-tailed) & LAG_IHSG & &, 031 &, 000 \\
& LAG_INFLASI &, 031 & &, 382 \\
& LAG_SGD &, 000 &, 382 & \\
\hline N & LAG_IHSG & 29 & 29 & 29 \\
& LAG_INFLASI & 29 & 29 & 29 \\
& LAG_SGD & 29 & 29 & 29 \\
\hline
\end{tabular}

Sumber: SPSS 20 
Hasil pengujian koefisien korelasi dapat disimpulkan sebagai berikut :

1. Inflasi berhubungan secara negatif dengan IHSG sebesar $0,350(r=-0,350)$

2. SGD berhubungan secara negatif dengan IHSG sebesar $0,588(r=-0,588)$

Hasil dari uji Signifikansi pada tabel diatas adalah :

$>$ Dengan menggunakan tingkat kepercayaan 5\% disimpulkan bahwa INFLASI dengan IHSG memiliki skor 0,031 dan 0,031 < daripada 0,05 maka dengan demikian korelasi antara kedua variabel adalah signifikan.

$>$ Dengan menggunakan tingkat kepercayaan 5\%, disimpulkan bahwa korelasi antara SGD dengan IHSG adalah signifikan.

\section{Koefisien Determinasi}

Tabel 3. Nilai Koefisien Determinasi

\begin{tabular}{|l|l|r|r|r|}
\hline Model & $\mathrm{R}$ & $\begin{array}{c}\mathrm{R} \\
\text { Square }\end{array}$ & $\begin{array}{c}\text { Adjusted } \\
\text { R Square }\end{array}$ & $\begin{array}{c}\text { Std. Error of the } \\
\text { Estimate }\end{array}$ \\
\hline 1 &, $668^{\mathrm{a}}$ &, 446 &, 404 & 180,07455 \\
\hline
\end{tabular}

Sumber: SPSS 20

Nilai koefisien determinasi ( $R$ Square) sebesar 0,668 atau 66,8\%. Hasil nilai tersebut menjelaskan bahwa fluktuasi IHSG dijelaskan oleh fluktuasi inflasi dan SGD sebanyak $66,8 \%$.

\section{Uji Normalitas}

Tabel 4. Uji Kolmogorov

\begin{tabular}{|ll|r|}
\hline & & \multicolumn{2}{|c|}{$\begin{array}{c}\text { Unstandardized } \\
\text { Residual }\end{array}$} \\
\hline N & Mean & 29 \\
Normal Parameters & a,b & $0 \mathrm{E}-7$ \\
& Std. Deviation & 173,52417734 \\
Most Extreme & Absolute &, 118 \\
Differences & Positive &, 054 \\
Kolmogorov-Smirnov Z & Negative &,- 118 \\
Asymp. Sig. (2-tailed) & &, 636 \\
\hline
\end{tabular}

Sumber: SPSS 20

Dengan tingkat signifikasi diatas $5 \%$. dapat dikatakan bahwa hasil uji Kolmogorov Smirnov memiliki nilai yang signifikan. Oleh karena itu, data terdistribusi secara normal dan sampel data yang digunakan bisa diestimasi dengan menggunakan regresi linier. 


\section{Uji Multikolinieritas}

Tabel 5. Uji Multikolinieritas

\begin{tabular}{|l|r|r|}
\hline \multirow{2}{*}{ Model } & \multicolumn{2}{|c|}{ Collinearity Statistics } \\
\cline { 2 - 3 } 1 (Constant) & Tolerance & \multicolumn{1}{|c|}{ VIF } \\
LAG_INFLASI &, 997 & 1,003 \\
LAG_SGD &, 997 & 1,003 \\
\hline
\end{tabular}

Sumber: SPSS 20

Dengan melihat pada nilai tolerance terhadap kedua variabel independen yang tidak ada yang memiliki nilai yang lebih besar dari 0,10 dan nilai VIF $<10$, maka hal ini dapat disimpulkan tidak terjadi multikolinearitas.

\section{Uji Heteroskedastisitas}

Supaya pengujian heteroskedastisitas dilakukan dengan lebih objektif, maka penelitian ini menggunakan Uji Glejser sebagaimana yang ada didalam tabel dibawah ini:

Tabel 6. Hasil Uji Glejser

\begin{tabular}{|c|c|c|c|c|c|}
\hline \multirow[b]{2}{*}{ Model } & \multicolumn{2}{|c|}{$\begin{array}{l}\text { Unstandardized } \\
\text { Coefficients }\end{array}$} & \multirow{2}{*}{$\begin{array}{c}\text { Standardized } \\
\text { Coefficients } \\
\text { Beta } \\
\end{array}$} & \multirow[b]{2}{*}{$\mathrm{t}$} & \multirow[b]{2}{*}{ Sig. } \\
\hline & B & $\begin{array}{l}\text { Std. } \\
\text { Error }\end{array}$ & & & \\
\hline 1 (Constant) & 154,724 & 311,784 & & ,496 & ,624 \\
\hline LAG_INFLASI & $-26,201$ & 108,949 &,- 047 &,- 240 & 812 \\
\hline LAG_SGD & ,001 & , 079 & ,003 & ,015 & ,988 \\
\hline
\end{tabular}

Sumber: SPSS 20

Hasil uji t yang didapatkan dengan meregresikan variabel SGD dan inflasi terhadap variabel Residual Absolut (RES2_2) didapatkan nilai signifikansi sebesar 0,988 > 0,05 dan $0,812>0,05$, sehingga dapat dikatakan bahwa kedua variabel tersebut tidak ada yang signifikan mempengaruhi variabel Residual Absolut (RES2_2). Kesimpulan dari hasil pengujian Glejser tersebut adalah pada penelitian ini tidak terdapat Heteroskedastisitas. 


\section{Uji Otokorelasi}

Tabel 7. Hasil Uji Otokorelasi

\begin{tabular}{|r|r|r|r|r|r|}
\hline \multicolumn{7}{|c|}{ Change Statistics } & \\
\cline { 1 - 5 } $\begin{array}{c}\mathrm{R} \\
\text { Square } \\
\text { Change }\end{array}$ & $\begin{array}{c}\mathrm{F} \\
\text { Change }\end{array}$ & \multicolumn{1}{c|}{ df1 } & \multicolumn{1}{c|}{ df2 } & $\begin{array}{c}\text { Sig. F } \\
\text { Change }\end{array}$ & $\begin{array}{c}\text { Durbin- } \\
\text { Watson }\end{array}$ \\
\hline ,446 & 10,486 & 2 & 26 &, 000 & 1,489 \\
\hline
\end{tabular}

Sumber: SPSS 20

Nilai Durbin Watson hitung berada di area DU dan 4-DU atau 1,566<1,489<2,4334. Oleh karena itu, tidak terdapat permasalahan otokorelasi pada model penelitian.

\section{Uji-F}

Tabel 8. Hasil Uji-F

\begin{tabular}{|l|c|r|c|c|c|}
\hline Model & \multicolumn{1}{|c|}{$\begin{array}{c}\text { Sum of } \\
\text { Squares }\end{array}$} & \multicolumn{1}{c|}{ df } & $\begin{array}{c}\text { Mean } \\
\text { Square }\end{array}$ & \multicolumn{1}{c|}{ F } & Sig. \\
\hline 1 Regression & 680038,494 & 2 & 340019,247 & 10,486 &, $000^{b}$ \\
& & & & & \\
$\quad$ Residual & 843097,923 & 26 & 32426,843 & & \\
$\quad$ Total & 1523136,418 & 28 & & & \\
\hline
\end{tabular}

Sumber: SPSS 20

Hasil uji F diatas yang memiliki nilai Sig. 0,00 mengatakan kepada kita bahwa skor Sig. yang bernilai 0,00 berada dibawah batas tingkat kepercayaan yaitu $5 \%$. Sehingga dapat disimpulkan bahwa SGD dan Inflasi secara silmutan berpengaruh signifikan terhadap IHSG.

\section{Uji-t}

Tabel 9. Hasil Uii-t

\begin{tabular}{|c|c|c|c|c|c|}
\hline \multirow[b]{2}{*}{ Model } & \multicolumn{2}{|c|}{$\begin{array}{c}\text { Unstandardized } \\
\text { Coefficients }\end{array}$} & \multirow{2}{*}{$\begin{array}{c}\text { Standardized } \\
\text { Coefficients } \\
\text { Beta } \\
\end{array}$} & \multirow[b]{2}{*}{$\mathrm{t}$} & \multirow[b]{2}{*}{ Sig. } \\
\hline & B & $\begin{array}{l}\text { Std. } \\
\text { Error }\end{array}$ & & & \\
\hline 1 (Constant) & 4380,565 & 480,318 & & 9,120 & ,000 \\
\hline LAG_INFLASI & $-364,371$ & 167,841 &,- 317 & $-2,171$ & ,039 \\
\hline LAG_SGD &,- 474 & ,122 &,- 570 & $-3,899$ & ,001 \\
\hline
\end{tabular}

Sumber: SPSS 20 
Setelah data diolah dengan melakukan pengujian hipotesis parsial menggunakan uji $t$, ditemukan bahwa variabel inflasi berpengaruh signifikan dengan skor 3,9\% dibawah koefisien kepercayaan $5 \%$ atau Sig. Inflasi $3,9 \%<5 \%$. Selanjutnya, variabel Dolar Singapura berpengaruh signifikan dengan skor $0,1 \%$ dibawah koefisien kepercayaan $5 \%$ atau Sig. SGD $0,1 \%<5 \%$.

Kemudian, dari nilai Beta nya dapat diketahui bahwa skor inflasi adalah $-364,371$, hal ini mengatakan bahwa fluktuasi inflasi memiliki negatif terhadap harga IHSG, sehingga semakin tinggi inflasi, akan mengakibatkan harga IHSG akan menurun. Selanjutnya dari nilai Beta Dolar Singapura juga diketahui variabel tersebut berpangaruh negatif dengan skor 0,474 . Akibat dari hal ini maka setiap terjadi Apresiasi mata uang Singapura terhadap Rupiah akan menurunkan harga IHSG.

\section{E. KESIMPULAN}

Berdasakankan penelitian yang sudah dilakukan untuk melihat apakah terdapat pengaruh SGD dan INFLASI terhadap IHSG, dapat dikemukakan beberapa hal dibawah ini:

1. Variabel independen Inflasi berpengaruh terhadap IHSG.

2. Variabel independen SGD berpengaruh negatif dan signifikan terhadap IHSG.

3. Secara simultan variabel SGD dan INFLASI terhadap IHSG, dapat secara bersamasama digunakan untuk mengestimasi variabel harga IHSG.

Penelitian yang kami lakukan menemukan bahwa Inflasi berhasil diketahui dapat berpengaruh signifikan terhadap IHSG. Hal ini menimbulkan implikasi bahwa kebijakan ekonomi makro yang berbentuk kebijakan fiskal dan moneter diketahui bisa membawa pengaruh terhadap IHSG dan pelaku pasar modal. Oleh karena itu, pemerintah perlu tetap bisa menjaga agar angka inflasi tetap berada pada target dan tidak mengalami inflasi yang keluar jalur.

Selanjutnya, pemerintah juga harus bekerjasama dengan sektor swasta dalam hal mengatur jadwal pembayaran hutang kepada Singapura. Karena apabila tidak diatur, maka akan menyebabkan disatu waktu tertentu Dolar Singapura akan mengalami apresiasi yang besar terhadap Rupiah, sehingga mengakibatkan IHSG akan mengalami penurunan yang besar.

\section{DAFTAR PUSTAKA}

Budiono. (2013). "Seri Sinopsis Pengantar Ilmu Ekonomi No. 2 Ekonomi Makro". Yogyakarta: BPFE- Yogyakarta.

Gargesa, D. S. (2018). "An Analytical Study of the Effect of Inflation on Stock Market Returns". International Journal of Management \& Social Sciences, 48-64.

Hakim, L., Sunardi, N. (2017). Determinant of leverage and it's implication on company value of real estate and property sector listing in IDX period of 2011-2015. Man in India, 97(24), pp. 131-148

Heru., N. \&. (2008). "Analisis Pengaruh Inflasi, Suku Bunga, Kurs dan Jumlah Uang Beredar Terhadap Indeks LQ 45 pada Bursa Efek Indonesia Periode 2002-2007", Tesis Dipublikasikan. Semarang : Universitas Diponegoro.

I Gusti Ayu Agung Omika Dewi, G. R. (2019). "Analisis Abnormal Return, Trading Volume Activity Dan Foreign Capital Inflow Sebelum Dan Sesudah Pemilihan Presiden Dan 
Pemilihan Legislatif Tahun 2019 (Studi Pada Perusahaan Anggota Indeks Kompas100 Di Bursa Efek Indonesia)" . Jurnal Ilmiah Akuntansi dan Bisnis , 204-220.

Kadim, A., Sunardi, N., \& Husain, T. (2020). The modeling firm's value based on financial ratios, intellectual capital and dividend policy. Accounting, 6(5), 859-870.

Lutfi, A. M., \& Sunardi, N. (2019). Pengaruh Current Ratio (Cr), Return On Equity (Roe), Dan Sales Growth Terhadap Harga Saham Yang Berdampak Pada Kinerja Keuangan Perusahaan (Pada Perusahaan Manufaktur Sektor Makanan Dan Minuman Yang Terdaftar Di Bursa Efek Indonesia). Jurnal SEKURITAS (Saham, Ekonomi, Keuangan dan Investasi), 2(3), 83-100.

Nuraina, K. L. (2015). "Peranan Inflasi, Bi Rate, Kurs Dollar (Usd/ldr) Dalam Mempengaruhi Indeks Harga Saham Gabungan". Jurnal Dinamika Manajemen , 73-83.

Purwanta, W. \&. (2006). "Mengenal Pasar Modal". Jakarta: Salemba Empat.

Putra, I. R. (2017). www.merdeka.com. Diambil kembali dari "https://www.merdeka.com/uang/Singapura-pemberi-utang-terbesar-ke-ri-nilainyatembus-rp-707-triliun.html".

Sugiyono. (2003). "Metode Penelitian Bisnis" . Bandung: Pusat Bahasa Depdiknas.

Sukirno, S. (2011). "Makroekonomi Teori Pengantar". Edisi ketiga. . Jakarta: PT Raja Grafindo Persada. .

Sunardi, N. (2018). Kinerja Perusahan Pendekatan Du Pont System Terhadap Harga Dan Return Saham (Perusahaan yang tergabung dalam Industri Real Estate dan Properti yang terdaftar di Bursa Efek Indonesia Tahun 2011-2017). JIMF (Jurnal IImiah Manajemen Forkamma), 1(3).

Sunardi, N. (2019). Profitabilitas, Likuiditas, Dan Multiplier Equity Pengaruhnya Terhadap Harga Serta Return Saham Pada Industri Manufaktur Tahun 2012-2017. INOVASI, 6(1), 58-73.

Sunardi, N., \& Ula, L. N. R. (2017). Pengaruh BI Rate, Inflasi Dan Kurs Terhadap Indeks Harga Saham Gabungan (IHSG). Jurnal Sekuritas: Saham, Ekonomi, Keuangan dan Investasi, 1(2), 27-41.

Sunariyah. (2011). "Pengantar Pengetahuan Pasar Modal" Edisi Keenam. Yogyakarta: UPP STIM YKPN.

Suryahadi, A. (2019, September 30). "https://investasi.kontan.co.id/news/ekonomi-tumbuhmelambat-langkah-ihsg-tersendat. Diambil kembali dari investasi.kontan.co.id: https://investasi.kontan.co.id/news/ekonomi-tumbuh-melambat-langkah-ihsgtersendat"

Wikipedia, S. (2015). "https://statistikceria.blogspot.com". Diambil kembali dari "https://statistikceria.blogspot.com/2013/12/download-dan-membaca-tabeldurbin.html"

Yurioputra. (2015). "Analisis Hubungan Antara IHSG dengan Nilai Tukar Rupiah Terhadap Mata Uang Negara ASEAN (Dollar Singapura, Ringgit Malaysia, Baht Thailand, Peso Filipina) Periode Tahun 2001-2013", Tesis Dipublikasikan. Depok: Universitas Indonesia.

Yusnita Jayanti, D. N. (2014). "Pengaruh Tingkat Inflasi, Tingkat Suku Bunga Sbi, Nilai Tukar Rupiah, Indeks Dow Jones Dan Indeks Klse Terhadap Indeks Harga Saham Gabungan (lhsg)". Jurnal Administrasi Bisnis Vol. 11, 1-10. 